\title{
(Re)estruturação do setor sucroenergético: formação e (re)territorialização da produção e do consumo de etanol no Brasil
}

\author{
(Re)structuring the sugar-energy sector: formation and \\ (re)territorialization of ethanol production and consumption in Brazil
}

\begin{abstract}
Altacir Bunde
\section{RESUMO}

A retomada da produção e do desenvolvimento das vendas de etanol hidratado no Brasil apresentou forte crescimento a partir dos primeiros anos do século XXI. Assim, sua produção e consumo ocorre de forma concentrada em uma determinada fração do território, o Centro-Sul do Brasil, tendo o estado de São Paulo como maior produtor e consumidor. Diante desses elementos, o presente artigo tem por objetivo analisar o processo de (re)estruturação do setor sucroenergético brasileiro, em especial a territorialização da produção e do consumo de etanol no país. Para tanto, realizou-se uma revisão teórica sobre o tema, assim como levantamento e análise de dados secundários sobre a produção e consumo. Como resultado, percebeu-se que a (re)estruturação do setor e a formação do mercado de etanol concentrou a produção no Centro-Sul do Brasil e, consequentemente, grande parte dessa produção é consumida nesse mercado construído pela grande presença de veículos flex fuel, mas, principalmente, pelas políticas de incentivos ao consumo desse produto, em especial, a redução do Imposto Sobre Circulação de Mercadorias e Serviços (ICMS). Tais incentivos vêm fazendo com que, no setor, permaneça uma política paternalista e protecionista. Portanto, o setor sucroenergético brasileiro se beneficiou e continua a se beneficiar da "generosidade" do Estado, motivo pelo qual cabe dar-Ihe a alcunha de Estado mãe.
\end{abstract}

Palavras-chave: (Re)estruturação; Territorialização; Setor Sucroenergético; Incentivos Fiscais

\section{ABSTRACT}

The resumption of production and development of sales of hydrous ethanol in Brazil showed strong growth from the first years of the 21st century. Thus, its production and consumption occurs in a concentrated way in a certain part of the territory, Center-Southern Brazil, which has the state of São Paulo as the largest producer and consumer. In view of these elements, this article aims to analyze the process of (re)structuring the Brazilian sugar-energy sector, in particular the territorialization of ethanol production and consumption in the country. Therefore, a theoretical review on the subject was carried out, as well as survey and analysis of secondary data on production and consumption. As a result, we have noticed that the (re)structure of the sector and the development of ethanol market have concentrated the production in Center-Southern Brazil, and, consequently, a large part of this production is consumed in this market built by the large presence of flexible-fuel vehicles, but mainly by policies of incentives to the consumption of this product, in particular, the reduction of the Tax on the Circulation of Goods and Services. Such incentives have been keeping a paternalistic and protectionist policy in the sector. Therefore, Brazilian sugar-energy sector has benefited and continues to benefit from the "generosity" of the State, which is why it may be called Mother State.

Keywords: (Re)structuring; Territorialization; Sugar-energy Sector; Tax breaks 


\section{INTRODUÇÃO}

No Brasil, a partir da cana-de-açúcar são produzidas três principais mercadorias: açúcar, álcool anidro (aditivo para gasolina) e álcool hidratado. O subproduto (bagaço) é utilizado para a geração de energia e/ou como lenha nas caldeiras. A cultura da cana-de-açúcar em maior proporção encontra-se localizada no Centro-Sul e no NorteNordeste do país.

A produção e o consumo de etanol abrangem parte de um sistema que ocorre de forma concentrada em uma determinada fração do território, o Centro-Sul do Brasil, que tem o estado de São Paulo como o maior produtor e consumidor dessa mercadoria. Portanto, é nessa fração do território que ocorre a produção e a realização da renda da terra e, por consequência, sua apropriação por parte do capital nacional e internacional.

No estado de São Paulo, em 2016, segundo dados da Associação Nacional dos Fabricantes de Veículos Automotores - ANFAVEA, estão concentrados 36,8\% da frota total de veículos do Brasil que usam etanol; 54,6\% da produção total de etanol anidro e 59,3\% da produção total de etanol hidratado, de acordo com informações da União da Indústria de Cana-de-Açúcar - UNICA. No referido estado também é consumido 58,3\% do total produzido de etanol no país, segundo dados da Agência Nacional do Petróleo -ANP. Assim, o estado de São Paulo é onde se produz e consome grande parte do etanol brasileiro. A territorialização numa fração do território da produção e do mercado de etanol não é algo natural, mas sim construído por meio de políticas de incentivos fornecidas pelo estado.

De acordo com os dados instigados no presente trabalho, não basta que alguns estados que são os maiores produtores de etanol hidratado tenham a maior presença do número de veículos flex fuel para que se possa, a partir daí, explicar o elevado consumo de etanol hidratado, especialmente nos estados do Centro-Sul. Porém, se esses estados não tivessem tornado o produto competitivo, capaz de concorrer com a gasolina tipo C, feito por meio das políticas de redução da taxa de 
ICMS e outros incentivos, a produção e o consumo de etanol não teriam evoluído da forma que ocorreu.

Diante de todos esses elementos, apesar de o discurso ser de livre concorrência que corresponde a formação dos preços do açúcar e do etanol, o que se observa é justamente o contrário. No setor, permanece a política paternalista e protecionista. Portanto, o setor sucroenergético brasileiro se beneficiou e continua a se beneficiar da "generosidade" do Estado, motivo pelo qual cabe dar-Ihe a alcunha de Estado mãe.

No que diz respeito aos fatores externos e internos que influenciaram a (re)estruturação do setor sucroenergético brasileiro e do mercado de etanol, segundo Bunde (2017), a forte expansão ocorreu, recentemente, mais precisamente a partir dos anos 2000, provocado por fatores relacionados: a) à elevação do preço internacional do petróleo; b) à produção dos carros flex fuel no país a partir de março de 2003, com o lançamento do Gol total flex pela Volkswagen; c) ao aumento do consumo interno de etanol como combustível de veículos automotores; d) ao aumento da adição de álcool anidro à gasolina; e) ao aumento na demanda dos mercados externos por açúcar após a desregulamentação comercial; f) ao aumento das preocupações referentes ao aquecimento global, entre outras.

Esses fatores possibilitaram o acúmulo de capital no setor sucroenergético, a qual, somada aos benefícios concedidos por meio da "generosidade" do Estado para com o setor, tiveram papel fundamental na (re)estruturação do setor no Brasil. Diante disso, objetiva-se analisar o processo de (re)estruturação do setor sucroenergético brasileiro, em especial, a formação e (re)territorialização da produção e do consumo de etanol no país. Para tanto, realizou-se uma revisão teórica sobre o tema, assim como levantamento e análise de dados secundários sobre a produção e consumo

A revisão teórica centrou-se em autores como: Andrade (1995); Baccarin (2005, 2007), Calabi e Indovina (1973); Costa e Guilhoto (2011); Lima (1992); Marx (2008); Oliveira (1999); Raffestin (1993); Shikida (1999), entre outros. Entre estes autores, há os que abordam conceitos e teorias relacionadas a uma visão crítica da geografia, da 
economia política, bem como há os que realizam análise do setor sucroenergético brasileiro.

Na pesquisa documental realizou-se um levantamento e análise de dados e de informações estatísticas, que orientaram tanto a pesquisa teórica, como a pesquisa secundária. Para isso, foi realizado consulta em sites de órgãos como: IBGE - Instituto Brasileiro de Geografia e Estatística; UNICA - União das Indústrias de Cana-de-açúcar; ANP - Agência Nacional do Petróleo, Gás Natural e Biocombustíveis; MAPA - Ministério da Agricultura, Pecuária e Abastecimento; ANFAVEA - Associação Nacional dos Fabricantes de Veículos Automotores, entre outros. Quando se tratou de examinar os dados e as estatísticas, informações etc. obtidas desses órgãos, o foco seguido foi a perspectiva adotada em relação às fontes, e não elas propriamente, embora, é claro, que às vezes as informações podem mudar a perspectiva de análise.

\section{ESTRUTURAÇÃO E DESESTRUTURAÇÃO DO SETOR SUCROENERGÉTICO BRASILEIRO}

Ao realizar-se uma abordagem do comportamento do setor sucroenergético, ou seja, como se deu a evolução da área plantada com cana-de-açúcar no Brasil, especialmente após os anos 1930, percebe-se que o setor evoluiu, sendo impulsionado tanto por elementos internos como externos. No período da safra 1948/1949 até 1974/1975, o crescimento da área plantada com cana-de-açúcar se manteve praticamente estável, mas, a partir da safra de 1974/1975, especialmente depois da safra 1981/1982 até a de 1985/1986, houve forte crescimento. Em 1980, a área plantada com cana-de-açúcar no Brasil, que era de 2.768.514 hectares, passou para 4.502.078 hectares em 1987, ou seja, quase que dobrou segundo dados do Ministério da Agricultura, Pecuária e Abastecimento - MAPA.

O crescimento nesse período se deu, principalmente, devido aos incentivos governamentais no setor com a criação do Programa Nacional do Álcool (PROÁLCOOL), em 1975. Esse período pode ser caracterizado como de estruturação do 
setor sucroenergético brasileiro. Cabe ressaltar que, a partir da safra de 1983/1984, houve uma redução na área plantada por fornecedores de cana de açúcar (matéria prima) para a manufatura de açúcar e etanol. Essa queda, porém, foi compensada pelo aumento da produção própria de cana de açúcar.

No período seguinte, de 1988 a 1993, o setor entrou em crise e apresentou queda na área plantada, isto é, caiu de 4.502.078 hectares para 3.953.047 hectares, em 1993, conforme dados do MAPA. A crise no setor se deu, principalmente, em função da queda nos preços internacionais do petróleo e à falta de alguns ajustes na tecnologia dos motores, que acabaram contribuindo para a queda do consumo de etanol. Além disso, a alta do preço do açúcar no mercado internacional influenciou o cultivo da cana, bem como o seu destino, que passou a priorizar a produção de açúcar.

Já no período que corresponde aos anos de 1994 a 1998, a área plantada apresentou novo crescimento e passou dos 3.953.047 hectares plantados para 5.050.153, em 1998. Esse crescimento ocorreu, dentre outros fatores, devido à política econômica de controle da inflação e melhoria do cenário interno e externo, principalmente para a comercialização de açúcar. No caso do Brasil, outro fator que influenciou foi o aumento do consumo de etanol anidro, que passou a ser adicionado à gasolina. O começo da década de 1990 também foi marcado pela desregulamentação no setor. Na Figura 01, pode-se visualizar a evolução da produção de cana-de-açúcar, própria e de fornecedores - safra 1948/1949 a 2013/2014.

No período que corresponde aos anos de 1998 a 2001, a área plantada com cana-de-açúcar se manteve praticamente estável. Fato este decorrente da crise financeira de 1999, da desregulamentação da economia, da abertura comercial e financeira ocorrida no período do segundo governo de Fernando Enrique Cardoso FHC (1999-2002) e da falta de incentivos governamentais para o setor.

Segundo Baccarin et al. (2007), no final do século XX, o setor sucroenergético brasileiro vivenciou uma grande e grave crise, que levou tanto à queda no consumo 
de álcool combustível como à permanência do preço de exportação do açúcar relativamente baixo, ou seja, entre US $\$ 150,00$ e US $\$ 200,00$ por tonelada.

Figura 01 - Brasil - Evolução da produção de cana-de-açúcar, própria e de fornecedores - safra 1948/1949 a 2013/2014

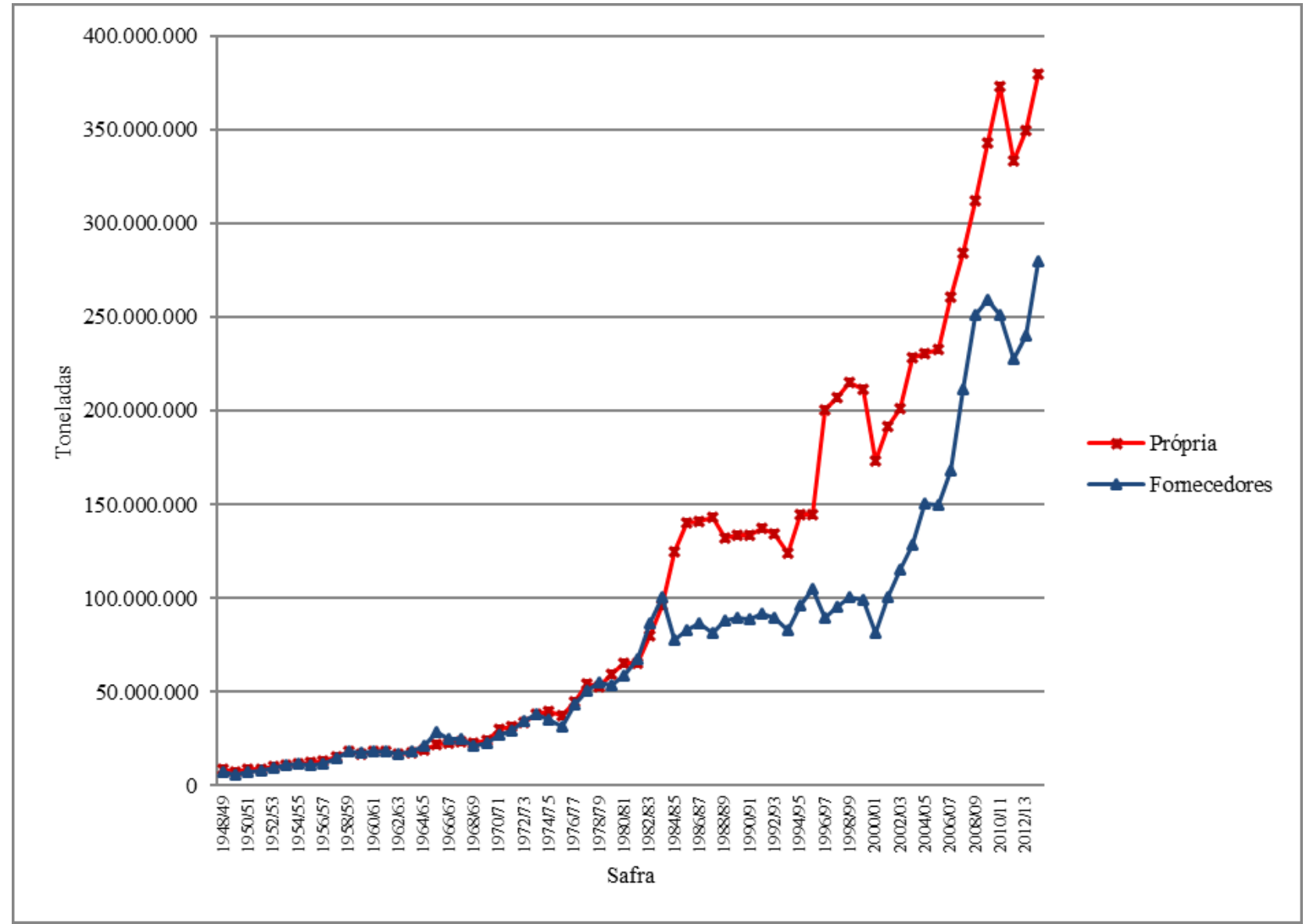

Fonte: Bunde (2017), elaborado a partir de dados do MAPA

Nesse período, com a queda do número de agroindústrias sucroalcooleiras, as perspectivas para o setor apontavam pequeno crescimento da produção e da estrutura produtiva. No caso do etanol, a diminuição da frota de carros movidos por esse tipo de combustível indicava que, dentro de alguns anos, seu consumo se resumiria ao do etanol anidro, usado em mistura à gasolina. Diante desse cenário, esse período pode ser caracterizado como de desestruturação do setor sucroenergético brasileiro. 

MERCADO BRASILEIRO DE ETANOL

Referir-se à produção de etanol implica tratar da produção de mercadorias. Isso porque, segundo Marx (2008), pode-se considerar como mercadoria tudo o que é produzido por meio do trabalho humano com a finalidade de ser vendido no mercado. Cabe destacar que existem mercadorias que não são criadas pelo trabalho humano, mas necessitam de trabalho para se tornarem úteis para o homem, como é o caso dos recursos naturais. É desse processo que deriva a sua natureza de mercadoria e o seu valor. Marx (2008, p. 57), em O Capital, livro I, v. I, afirma que:

A riqueza das sociedades em que rege o modo-de-produção capitalista configura-se como uma "imensa acumulação de mercadorias" [...] A mercadoria é, antes de mais nada, um objeto externo, uma coisa que, pelas suas propriedades, satisfaz necessidades humanas, seja qual for a natureza, a origem delas, provenha do estômago ou da fantasia. Não importa a maneira como a coisa satisfaz a necessidade humana, se direta ou indiretamente, como meio de subsistência, objeto de consumo, ou indiretamente, como meio de produção. Cada coisa útil, como o ferro, o papel etc., pode ser considerada sob um duplo aspecto, segundo qualidade e quantidade. Cada um desses objetos é um conjunto de muitas propriedades e pode ser útil de diferentes modos. Constitui fatos históricos a descoberta dos diferentes modos, das diferentes maneiras de usar as coisas, e a invenção de medidas, socialmente aceitas, para quantificar as coisas úteis. A variedade dos padrões de medida das mercadorias decorre da natureza diversa dos objetos a medir e também de convenção.

Nesse sentido, como mostra Marx, compreender o conceito de mercadoria é central para que se possa entender o modo capitalista de produção e, consequentemente, o setor sucroenergético brasileiro, mais especificamente a produção de etanol.

Segundo Marx, "Para criar mercadoria, é mister não só produzir valor de uso, mas produzi-lo para os outros, dar origem a valor de uso social [...] nenhuma coisa pode ser valor se não é objeto útil" (MARX, 2008, p. 63, grifo nosso). Marx faz essa 
análise das mercadorias a partir da teoria do valor trabalho. É a partir daí que ele resolve o problema na identificação do que realmente contribui para o estabelecimento do valor de troca das mercadorias. Por isso, afirma:

As mercadorias [...] só são mercadorias por sua duplicidade, por serem ao mesmo tempo objetos úteis e veículos de valor. Por isso, patenteiam-se como mercadorias, assumem a feição de mercadoria, apenas na medida em que possuam dupla forma, aquela forma natural e a de valor (MARX, 2008, p. 69).

Para Marx (2008), as mercadorias possuem valor porque nelas está contido o trabalho humano, o que faz com que seu valor seja uma realidade puramente social, tornando-se evidente que essa realidade social também só se pode manifestar nas transações sociais, ou seja, nas relações das mercadorias umas com as outras. É por esse motivo que se parte do valor de troca ou da relação de troca das mercadorias para se chegar ao seu valor, que nela está escondido. Para o autor, as mercadorias possuem uma forma-valor (comum) que contrasta, da maneira mais flagrante, com as suas múltiplas formas naturais - é a forma-dinheiro.

Nesse sentido, entende-se por mercadoria tudo aquilo que é produzido para o mercado, ou seja, o que é produzido para vender e não somente para o consumo imediato do produtor. No entanto, cabe salientar que a produção de mercadorias já existia antes do capitalismo, mas foi do modo de produção capitalista que ela se generalizou. Isso ocorreu porque, com a expansão do capitalismo, foi expandindo seu sistema de produção para o mercado em âmbito mundial. Por isso, costuma-se dizer que o capitalismo é o modo de produção que mercantilizou a vida humana e os recursos naturais, isto é, tudo no capitalismo se transforma em mercadoria e pode ser medido em dinheiro. É por esse motivo que, ao tratar-se do etanol como combustível, trata-se da produção e do uso de mercadorias que possuem, ao mesmo tempo, valor de uso e valor de troca.

A partir dos anos 2000, mais especificamente a partir de 2003, devido a um conjunto de fatores, o setor sucroenergético brasileiro chegou a uma nova fase de 
expansão e de (re)estruturação. Nesse sentido, a nova fase de grande expansão da área plantada de cana-de-açúcar, que vai formar o atual setor sucroenergético, ocorreu a partir do ano de 2002. Nesse período, a área plantada com cana, que era de 5.022.490 em 2001, saltou para 10.670.847 em 2015, segundo dados da CONAB e da União da Indústria de Cana-de-Açúcar (UNICA). Assim, como no período do PROÁLCOOL, a área plantada com cana-de-açúcar dobrou, o que caracteriza esse período como de (re)estruturação do setor sucroenergético brasileiro.

Figura 02 - Brasil - Evolução da quantidade de cana-de-açúcar processada (em mil toneladas) - safra 1980/81 a 2014/15

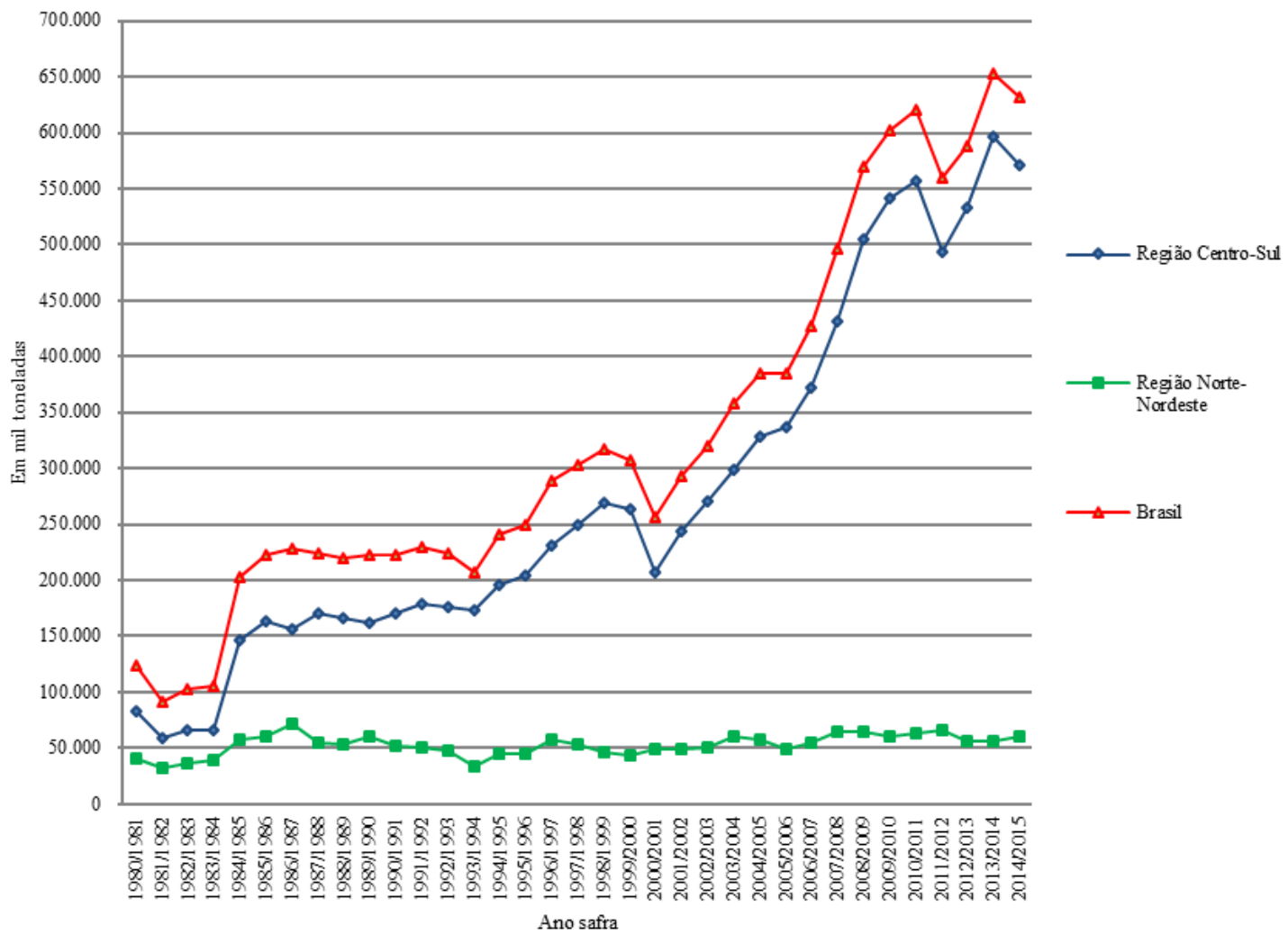

Fonte: Bunde (2017) elaborado a partir de dados da UNICA, 2016

No que diz respeito à quantidade de cana-de-açúcar produzida, segundo dados da UNICA, o Brasil produziu, na safra 2015/2016, cerca de 658,7 milhões de toneladas. 
No que diz respeito à produção de etanol total, ela consolidou-se em 28,66 bilhões de litros na safra 2014/2015. Na Figura 02, pode-se observar a evolução da quantidade de cana-de-açúcar processada entre as safras 1980/1981 a 2014/2015.

Atualmente, o mercado global de energia diz respeito a vários produtos energéticos (óleo, gás, carvão, nuclear, hidrelétrica e outros renováveis, como o etanol), sendo que, na visão de Pinto Júnior et al. (2007), as novas tecnologias tornaram possível o uso de dois ou mais tipos de combustível sem a troca de equipamento, sendo um dos exemplos os veículos flex. Originada, principalmente, devido ao Primeiro Choque do Petróleo, a consequência natural dessa flexibilidade tecnológica foi que esses produtos passaram a ser substitutos e concorrentes entre si, gerando uma total interdependência.

Nesse sentido, a retomada da produção e do crescimento das vendas de etanol hidratado, no Brasil, apresentou forte crescimento a partir do lançamento no mercado dos veículos flex fuel, em março de 2003. A esse acontecimento se soma o aumento da renda da população brasileira no período e, consequentemente, do consumo, quanto à substituição da gasolina pelo etanol. Segundo (COSTA, 2008 p. 43):

O início da comercialização, em 2003, de veículo bicombustível, também conhecido como flex fuel, proporcionou um novo impulso para o setor sucroenergético. Esses veículos podem usar indiscriminadamente álcool ou gasolina $C$, sem a necessidade de nenhuma adaptação ou ajuste. O desenvolvimento dessa tecnologia se deu graças ao investimento em pesquisa e desenvolvimento (P\&D) pelos fabricantes de sistemas de injeção direta na produção de sistemas eletrônicos que ajustam automaticamente a combustão em função do tipo de combustível.

Para Bunde (2017), o lançamento, em 2003, dos carros flex provocou uma "revolução" no mercado automobilístico brasileiro e, consequentemente, no setor sucroenergético, pois tais automóveis com motores flex fuel são capazes de funcionar 
com etanol hidratado, gasolina ou qualquer mistura dos dois combustíveis. Esse fato permitiu que a escolha sobre o uso do combustível não mais se dava no momento da compra do veículo, mas sim na bomba de combustível, na hora de abastecer.

Além disso, a partir de 2003, segundo Bunde (2017), ocorreram alguns fenômenos de caráter mundial: a invasão do Iraque pelos EUA, que suscitou a questão estratégica da dependência do petróleo; as consequências do furacão Katrina, em agosto de 2005, na Região Sul dos EUA, que revelou, de forma contundente, a face ameaçadora do aquecimento do planeta, provocado pelos gases que causam o efeito estufa, em especial, o dióxido de carbono, emitido pela atividade humana, particularmente pela queima de derivados de petróleo; o início da escalada de preços do petróleo, que multiplicou por cinco seus preços. Assim, o álcool etílico combustível (etanol), que era uma exclusividade brasileira, passou a ser assunto de discussão de um enorme contingente de países em todo o mundo.

Desse modo, tanto os fatores externos (subida do preço do petróleo e as preocupações com aquecimento global) como internos influenciaram decisivamente a expansão da produção e do uso de etanol (hidratado e anidro) como combustível. Bunde (2017, p. 24), diz que,

[...] esse processo de reestruturação do setor sucroenergético no Brasil, a partir dos anos 2000, foi provocado por fatores relacionados: a) à elevação do preço internacional do petróleo; b) à produção dos carros flex fuel no país, a partir de março de 2003, com o lançamento do gol total flex pela Volkswagen; c) ao aumento do consumo interno de etanol como combustível de veículos automotores; d) ao aumento da adição de álcool anidro à gasolina; e) ao aumento na demanda dos mercados externo por açúcar após a desregulamentação comercial; f) ao aumento das preocupações referentes ao aquecimento global e; g) entre outras, que levou o setor a uma nova fase

Esse cenário, provocou mudança, também, na fabricação e no mercado interno brasileiro de automóveis, que teve grande crescimento, especialmente a partir de 2003, como pode ser observado na Figura 03. 
Figura 03 - Brasil - Produção de automóveis por tipo de combustível - 1979-2014

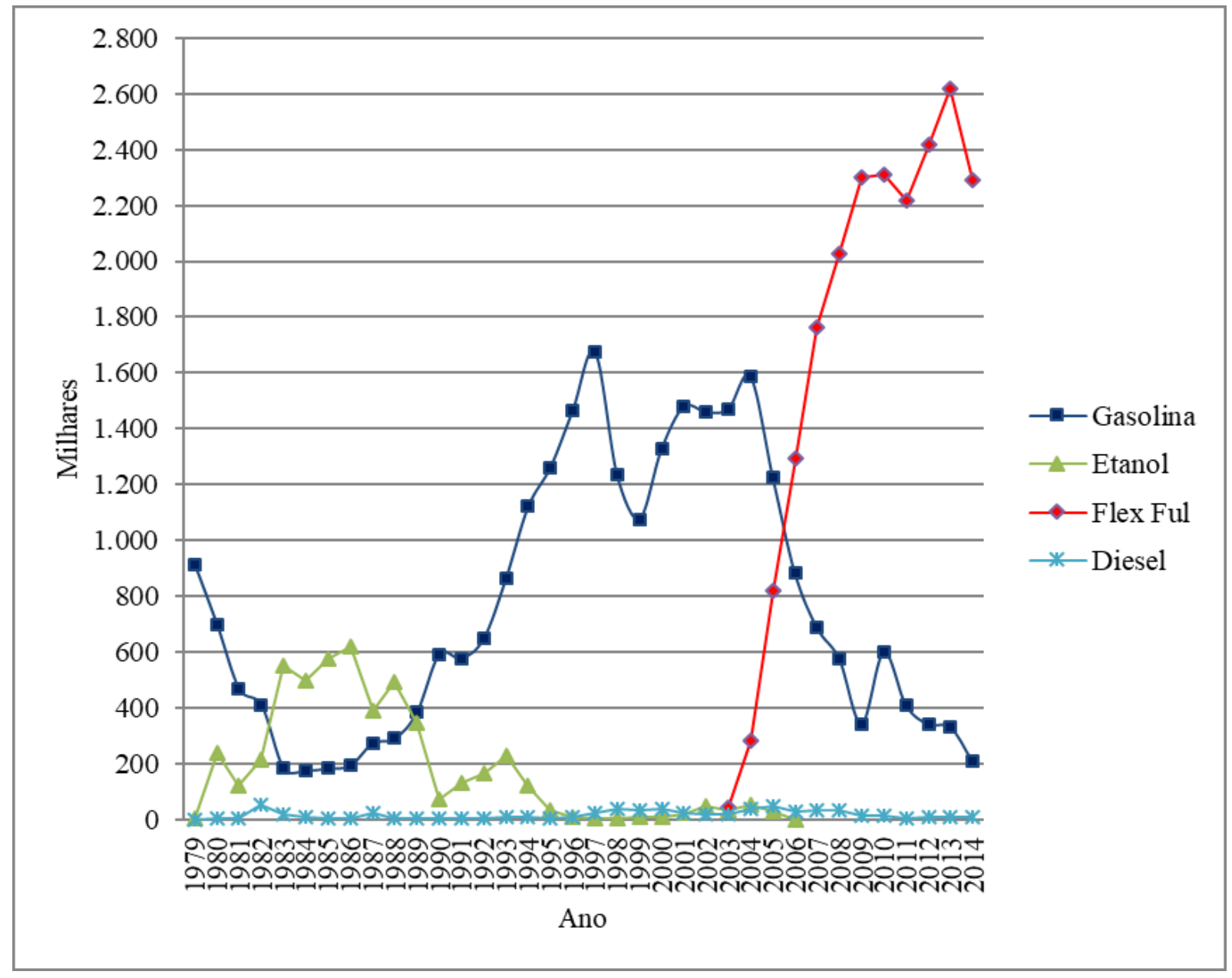

Fonte: Bunde (2017), elaborado a partir de dados da ANFAVEA, 2016

Toda essa expansão ocorreu porque o capitalismo, no Brasil e no mundo, organizou a economia baseada na fabricação de veículos de transporte individual, o automóvel. Todo esse processo fez com que as grandes cidades se transformassem num verdadeiro caos, com quilômetros de congestionamentos, o que tem levado ao aumento do aquecimento global e à alteração do clima devido à poluição provocada pelo funcionamento dos motores de combustíveis de origem fóssil. Esse fator tem influenciado a busca de energia alternativa, dentre elas, o etanol. Em função disso, tanto a produção como o consumo de etanol vêm crescendo nos últimos anos. 


\section{TERRITORIALIZAÇÃO DA PRODUÇÃO, DO CONSUMO DE ETANOL E PRESENÇA DE VEÍCULOS NO} BRASIL

No que diz respeito à produção e o consumo de etanol, trata-se de um sistema que ocorre de forma concentrada em uma determinada fração do território, o CentroSul do Brasil, com grande concentração no estado de São Paulo, que é o maior produtor e consumidor dessa mercadoria. É nessa fração do território que ocorre a produção e a realização da renda da terra e, por consequência, sua apropriação por parte do capital nacional e internacional. Entretanto, antes de seguir nessa discussão, faz-se uma pequena abordagem sobre o conceito e o processo de construção de território, defendido por Oliveira (1999, p. 74-75):

O processo de construção do território é simultaneamente construção/destruição/manutenção/transformação. Em síntese, é a unidade dialética, portanto contraditória, da espacialidade que a sociedade tem e desenvolve. Logo, a construção do território é contraditoriamente o desenvolvimento desigual, simultâneo e combinado, o que quer dizer: valorização, produção e reprodução. [...] É essa lógica contraditória que constrói/destrói formações territoriais em diferentes partes do mundo ou faz com que frações de uma mesma formação territorial conheçam processos desiguais de valorização, produção e reprodução do capital, conforme regiões.

Para Calabi e Indovina (1992, p. 57), “existe um uso do território, por parte do capital, diverso e sujeito a contínuas modificações, em correspondência com as diversas fases de desenvolvimento do processo produtivo". No entanto, segundo os autores, a construção de um território pela ação capitalista é repleta de intencionalidades e ações políticas que acabam por materializar as contradições do capitalismo.

Raffestin (1993), por sua vez, argumenta que o espaço é anterior ao território de modo que o território deve ser tratado conforme seu caráter político-administrativo. Nesse sentido, segundo ele, é ao se apropriar de um espaço que os sujeitos territorializam esse espaço. Desse modo, o território deve ser entendido como um espaço no qual se projetou um trabalho, como a produção de cana-de-açúcar, que, 
por consequência, passa a revelar marcas de poder. Nesse sentido, o território se apoia no espaço, não o espaço em si, mas uma produção realizada a partir do espaço, produção complexa e eivada de relações que envolvem, também, o campo de poder.

Seguindo na mesma linha de raciocínio que Raffestin (1993), Manoel Correa de Andrade (1995), ao tratar da ideia de território, diz que esse conceito não deve ser confundido com o de espaço ou de lugar. As análises sobre território devem ser feitas, diz o autor, a partir da ideia de poder.

O conceito de território não deve ser confundido com o de espaço ou de lugar, estando muito ligado à ideia de domínio ou de gestão de uma determinada área. Deste modo, o território está associado à ideia de poder, de controle, quer se faça referência ao poder público, estatal, quer ao poder das grandes empresas que estendem os seus tentáculos por grandes áreas territoriais, ignorando as fronteiras políticas. (ANDRADE, 1995, p. 19).

A partir disso, segue-se essa ideia de território, abordado anteriormente por Oliveira (1999), Raffestin (1993), Calabi e Indovina (1992), e Andrade (1995).

No que diz respeito a territorialização da produção de etanol, na safra de 2003/2004, o estado de São Paulo já era o maior produtor, respondendo por 49,12\% da produção total de etanol do país (2.879 $\mathrm{mil} \mathrm{m}^{3}$ ). Em seguida, na ordem decrescente entre os dez principais estados produtores, vem os seguintes estados: Paraná 12,49\% $\left(732 \mathrm{mil} \mathrm{m}^{3}\right)$, Alagoas 7,46\% (437 mil m³), Minas Gerais 6,65\% (390 mil m³), Mato Grosso 5,34\% (313 mil m³), Goiás 4,66\% (273 mil m³), Mato Grosso do Sul 4,45\% (261 mil m³), Pernambuco 2,87\% (168 mil m³), Paraíba 2,58\% (151 mil m³) e Rio de Janeiro, com 1,16\% (68 mil $\mathrm{m}^{3}$ ) na participação total de etanol hidratado segundo dados da ANP.

Diante disso, ao se analisar a produção de etanol por estado, entre as safras 2003/2004 até 2015/2016, destacados nas Figuras 04 e 05, observam-se grandes mudanças territoriais na produção de etanol hidratado no país. Ou seja, há uma (re)estruturação territorial da produção de etanol hidratado no Brasil que provocou uma mudança na participação dos estados, com exceção de São Paulo, na produção desta mercadoria. 
Figura 04 - Brasil - Produção de etanol hidratado por Estado - safra 2003/2004 (em mil $\mathrm{m}^{3}$ )

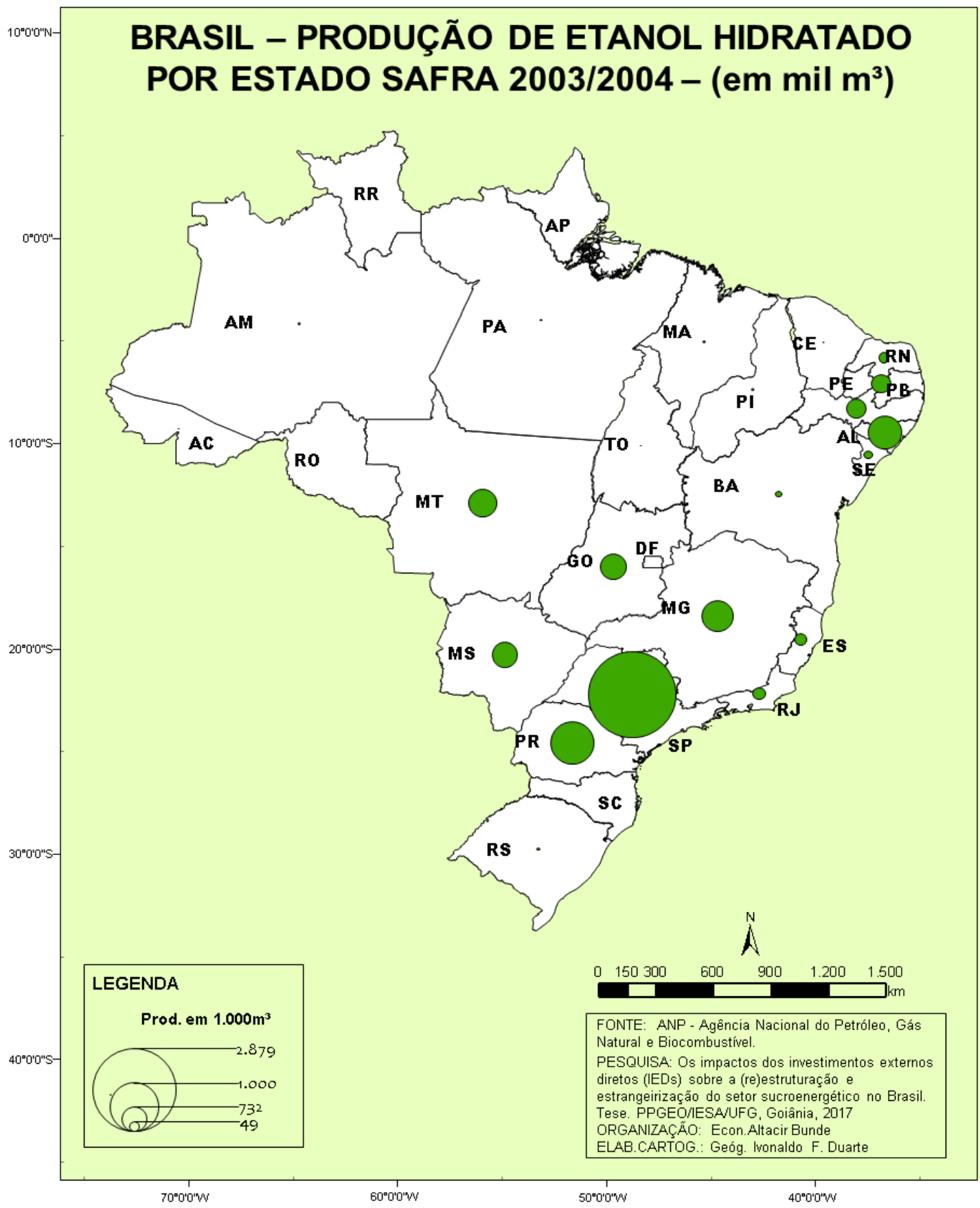

Fonte: Bunde e Duarte (2017), elaborado a partir de dados da ANP 
Figura 05 - Brasil - Produção de etanol hidratado por Estado - safra 2015/2016 (em mil m³)

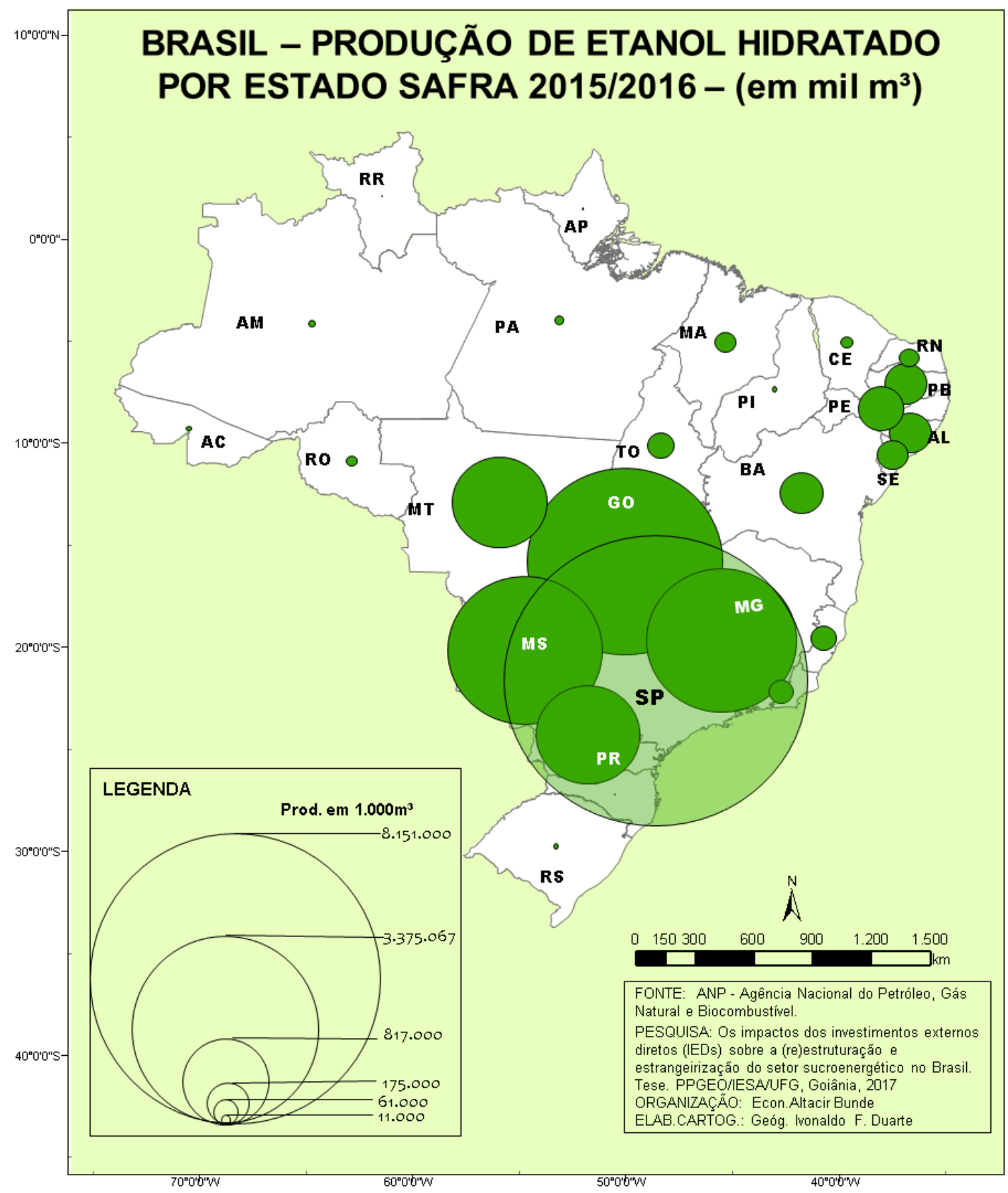

Fonte: Bunde e Duarte (2017), elaborado a partir de dados da ANP 
Para se ter uma ideia da evolução da produção brasileira de etanol hidratado total, no período safra 2003/2004 a 2015/2016, a produção no país cresceu 318\%, saltando de $5.861 \mathrm{~m}^{3}$ para $18.572 \mathrm{~m}^{3}$, segundo dados da ANP.

Na safra de 2015/2016, segundo dados da ANP, o estado de São Paulo respondeu por 43,89\% da produção total do país (8.151 $\mathrm{mil} \mathrm{m}^{3}$ ); em segundo lugar, estava o estado de Goiás, com participação de 18,17\% (3.375 mil m³); em terceiro, o estado de Mato Grosso do Sul, com 11,48\% (2.131 mil m³); em quarto, Minas Gerais, com 10,82\% (1.010 m³); em quinto colocado, o estado do Paraná, com 5,24\% (972 mil $\mathrm{m}^{3}$ ); o estado de Mato Grosso na sexta colocação, com uma participação de 4,40\% (818 mil m³); em sétimo lugar, estava Pernambuco, com uma participação de 1,05\% (196 mil m³); em oitavo, o estado de Pernambuco, com participação de 0,90\% (168 mil $\mathrm{m}^{3}$ ); em nono lugar, estava o estado da Paraíba, com uma participação de 0,88\% (165 mil $\mathrm{m}^{3}$ ); e, em décimo lugar, o estado de Alagoas, com 0,87\% (163 mil m³) na participação total de etanol hidratado.

Um dos fatos importantes a ser observado na produção de etanol hidratado diz respeito à participação dos estados da Região Norte-Nordeste na produção total. Estes, que respondiam por 17,59\% na safra 2003/2004, caíram para apenas 5,33\% na safra 2015/2016. Desse modo, a expansão da produção dessa mercadoria ocorreu no Centro-Sul do país, com destaque para os estados de São Paulo, Goiás, Minas Gerais e Mato Grosso Sul. Tais estados se tornaram os principais produtores de etanol hidratado, assim como, em alguns deles, os principais consumidores.

Portanto, observa-se que a formação do mercado de etanol hidratado no Brasil passou por um processo de transformação e (re)estruturação entre os anos de 2004 e 2016. Em 2004, o consumo de etanol hidratado estava distribuído pelos estados da federação e seu consumo não se dava, necessariamente, próximo de onde era produzido, embora, em alguns estados, como é o caso de São Paulo, toda a produção do estado era ali, também, consumida.

Conforme a Figura 06, o estado de São Paulo já era o maior consumidor dessa mercadoria em 2004, segundo dados da ANP, respondendo por 49,99\% do consumo 
Figura 06 - Brasil - Venda de etanol hidratado por estado - $2004(\mathrm{em} \mathrm{mil} \mathrm{m³)}$

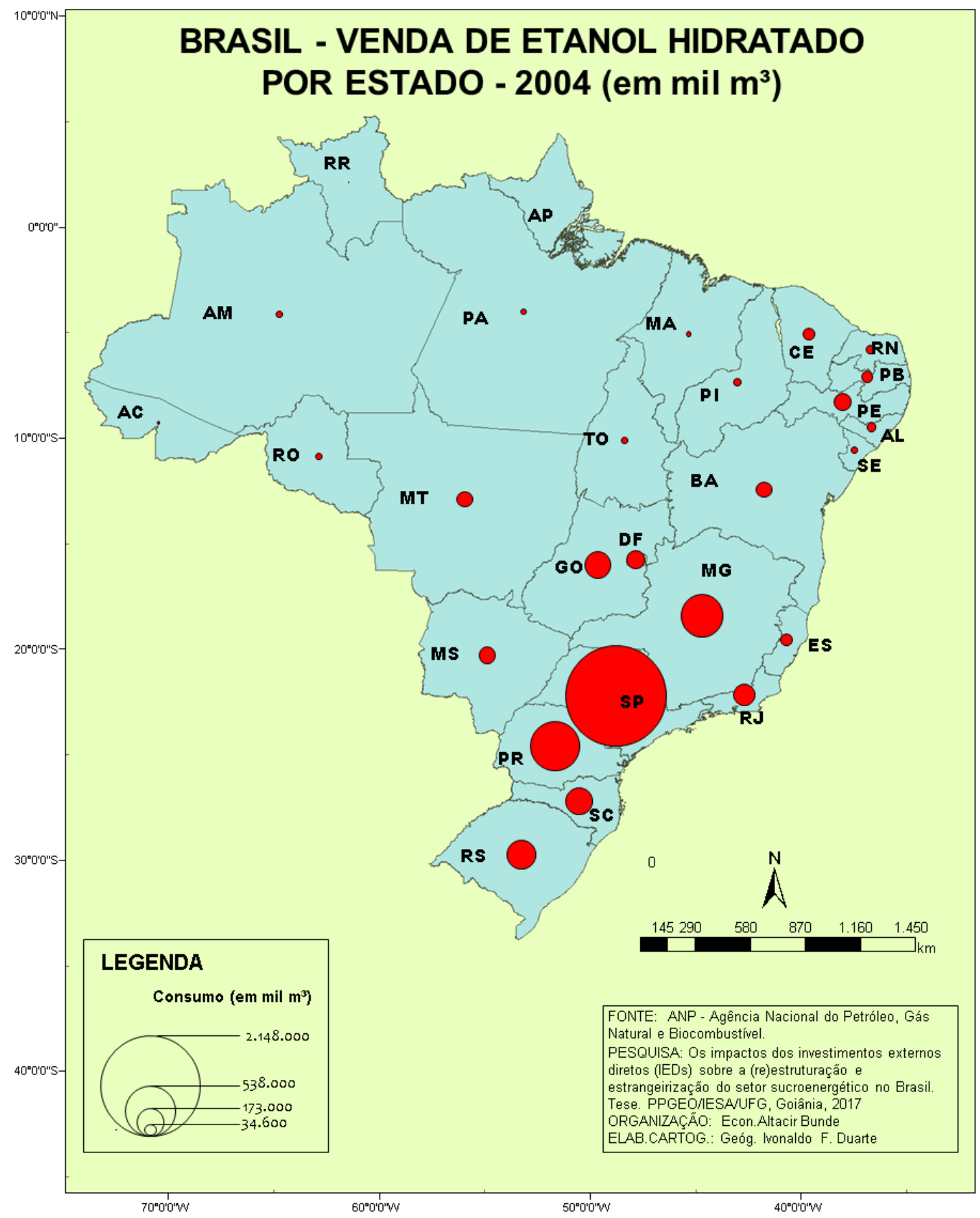

Fonte: Bunde e Duarte (2017), elaborado a partir de dados da ANP 
Figura 07 - Brasil - Vendas de etanol hidratado por Estado - $2016\left(\mathrm{em} \mathrm{mil} \mathrm{m}{ }^{3}\right)$

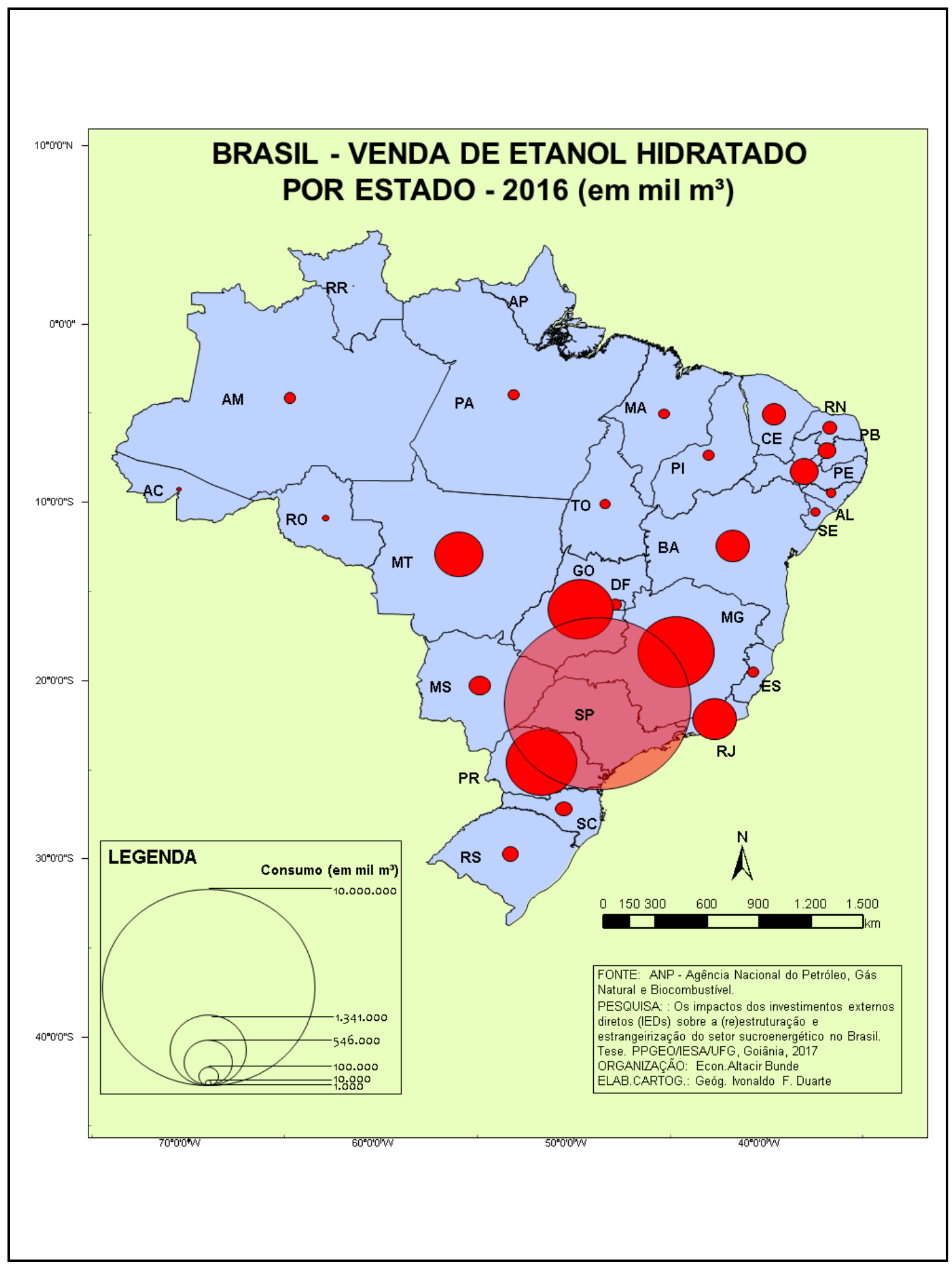

Fonte: Bunde e Duarte (2017), elaborado a partir de dados da ANP 
total do país $\left(2.148,81 \mathrm{mil} \mathrm{m}^{3}\right)$. Seguindo uma ordem decrescente dos dez principais estados brasileiros no consumo de etanol hidratado, em segundo lugar, o estado do Paraná, com participação de 12,53\% (538,59 mil m³); em terceiro, o estado de Minas Gerais, com 9,33\% (401,00 mil m³); em quarto, o estado do Rio Grande do Sul, com 4,47\% (192,01 mil m³); em quinto lugar, Santa Catarina, com 4,02\% (173,02 mil m³); em sexto colocado, o estado de Goiás, com 3,63\% (155,90 mil $\left.\mathrm{m}^{3}\right)$; o estado do Rio de Janeiro aparece na sétima colocação, com uma participação de 2,55\% (109,82 mil m³); em oitavo lugar, o Distrito Federal, com uma participação de 1,77\% (76,20 mil m³); em nono, o estado do Mato Grosso do Sul com participação de 1,66\% (71,21 mil m³); e, em décimo lugar, o estado de Pernambuco, com uma participação de 1,61\% (69,22 mil $\left.m^{3}\right)$.

Esse cenário mudou com a expansão e (re)estruturação do setor, conforme se pode observar comparando-se a Figura 06 com a Figura 07. Em dezembro de 2016, o estado de São Paulo passou a consumir mais etanol hidratado do que produz. Assim, além de um grande produtor, tornou-se, também, importador de etanol hidratado de outros estados.

Em dezembro de 2016, São Paulo passou a responder por 57,32\% do consumo total do país $\left(7.705 .308 \mathrm{~m}^{3}\right.$ ) segundo dados da ANP; em segundo lugar, estava o estado de Minas Gerais, com participação de 9,98\% (1.341.762 $\left.\mathrm{m}^{3}\right)$; em terceiro, o estado do Paraná, com 8,55\% (1.149.964 $\mathrm{m}^{3}$ ); em quarto lugar, Goiás, com 7,27\% (976.787 $\mathrm{m}^{3}$ ); em quinto, o estado de Mato Grosso, com 4,06\% (546.402 $\left.\mathrm{m}^{3}\right)$; o estado do Rio de Janeiro aparecia na sexta colocação, com participação de 3,29\% (441.693 $\left.\mathrm{m}^{3}\right)$; em sétimo lugar, Bahia, com participação de 2,09\% (280.946 $\left.\mathrm{m}^{3}\right)$; em oitavo, o estado de Pernambuco, com participação de 1,40\% (187.964 $\mathrm{m}^{3}$ ); em nono, o estado do Ceará, com participação de 0,97\% (130.843 $\mathrm{m}^{3}$ ); em décimo, o estado do Mato Grosso do Sul, com 0,79\% (106.827 $\left.\mathrm{m}^{3}\right)$.

Pelas Figuras 04, 05, 06 e 07, observa-se que a produção e o consumo de etanol hidratado se concentram numa determinada fração do território brasileiro, isto é, o consumo se dá na mesma e/ou próximo à fração do território onde é produzido. Isso 
ocorre por dois motivos: a presença de automóveis flex fuel e os incentivos fiscais concedidos pelos governos desses estados.

Segundo a Associação Nacional de Fabricantes de Veículos Automotores (ANFAVEA), da frota brasileira de veículos, em 2004, a maioria dos veículos eram automóveis e somavam quase 23 milhões de unidades representando $78 \%$ do total. Em 2014, a frota brasileira total de veículos chegou a 41,7 milhões. O número inclui automóveis, comerciais leves, caminhões e ônibus que rodavam no país. Desse total, 39 milhões eram automóveis e veículos leves. Soma-se a isso a existência, em 2014, de mais de 13 milhões (13.118.903) de motocicletas circulando no país.

Já em 2016, segundo dados do Ministério das Cidades, do Departamento Nacional de Trânsito (DENATRAN) e do Registro Nacional de Veículos Automotores (RENAVAM), a frota que, em 2004, era de 23.757.230, saltou para 51.296.982, em dezembro de 2016. Assim, no período, a frota nacional de automóveis mais que dobrou, conforme pode ser observado comparando-se as Figuras 08 e 09.

No que diz respeito à sua concentração, observa-se que grande parte da frota brasileira de automóveis está concentrada no estado de São Paulo, que, em dezembro de 2016, possuía 36,8\% do total; em seguida, vem Minas Gerais, com 10,36\%; Rio de Janeiro, com 8,98\%; Rio Grande do Sul, com 8,50\%; Paraná, com 8,15\%; e Santa Catarina, com 4,90\%. Somados, esses seis estados respondem por 77,69\% do total da frota de automóveis que transitavam no país no final de 2016.

Diante desses dados, ao analisarem-se os Figuras 08 e 09 e compará-los com os Figuras 06 e 07, percebe-se que o consumo de etanol hidratado no país não segue, necessariamente, a distribuição da frota de automóveis. Se seguisse, os estados do Rio Grande do Sul, Santa Catarina e Rio de Janeiro deveriam estar entre os maiores consumidores de etanol hidratado do país, pois ocupam lugar de destaque na presença de automóveisi. 
Figura 08- Brasil - Frota de automóveis por Estado - 2004

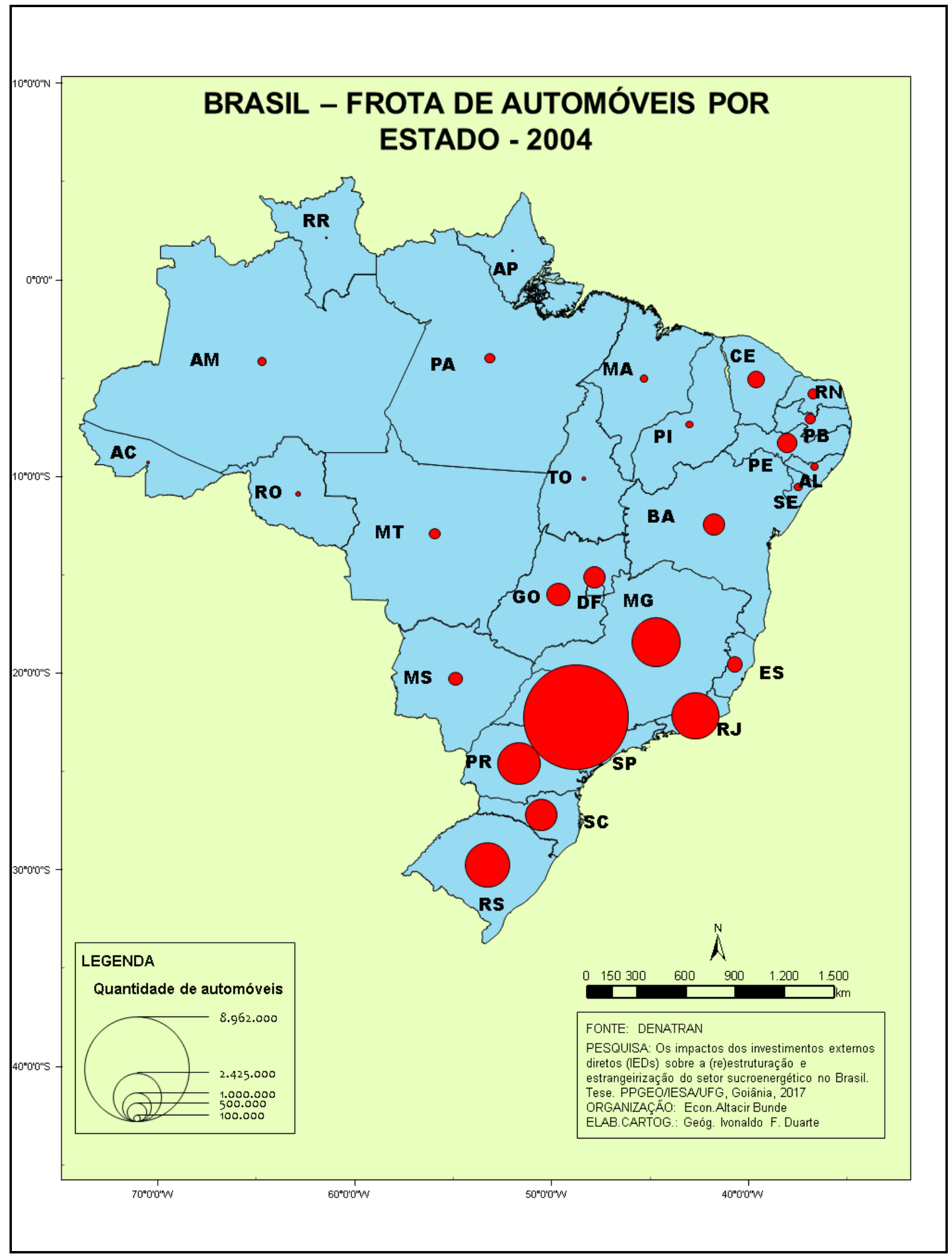

Fonte: Bunde e Duarte (2017), elaborado a partir de dados do DENATRAN 
Figura 09 - Brasil - Frota de automóveis por Estado - dezembro de 2016

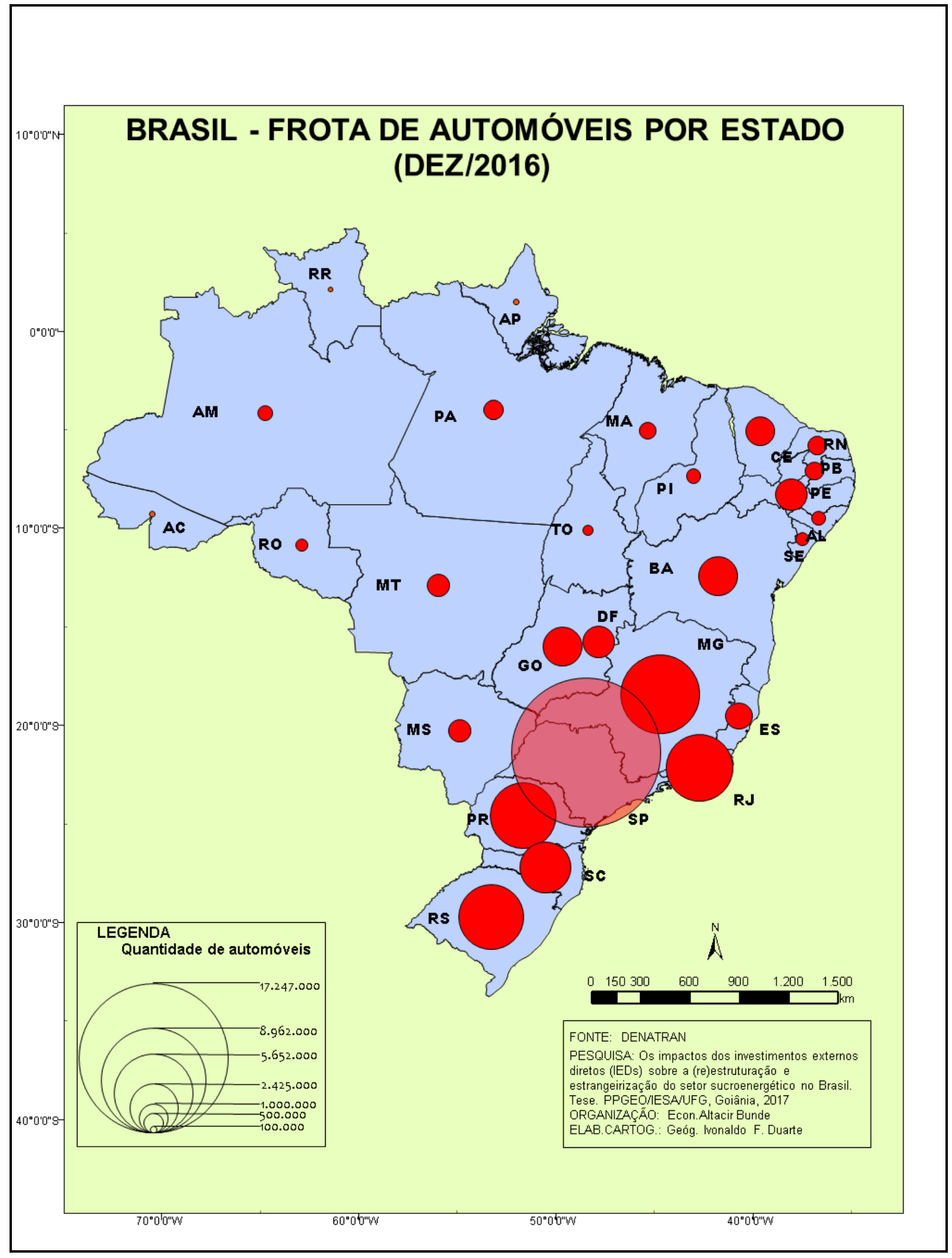

Fonte: Bunde e Duarte (2017), elaborado a partir de dados do DENATRAN e RENAVAM 
Diante desses dados, constata-se que não basta a existência da produção de etanol hidratado numa determinada fração do território, assim como não basta a concentração de automóveis para explicar o consumo de etanol hidratado no Brasil. O fator mais importante para explicar a concentração numa determinada fração do território do consumo de etanol hidratado são os incentivos fiscais concedidos pelos governos estaduais.

\section{POLÍTICAS DE INCENTIVO AO CONSUMO DE ETANOL NO BRASIL: O ESTADO MÃE}

O que era preciso ser feito, e foi feito por parte de alguns governos estaduais, foi tornar o etanol hidratado competitivo diante da gasolina. Isso foi possível via redução do ICMS sobre o etanol hidratado. Foi assim que o produto se tornou mais competitivo perante a gasolina em alguns estados do país.

Segundo Bunde (2011), um dos elementos que vem influenciando a (re)estruturação do setor sucroenergético brasileiro por meio do consumo de etanol é o preço desse combustível quando comparado ao preço da gasolina. Cálculos realizados indicam que é mais vantajoso abastecer veículo flex fuel com etanol quando seu preço (por litro) for inferior a $70 \%$ do preço do litro da gasolina. Isso ocorre porque, segundo estudos, o consumo de etanol é superior ao de gasolina comparando-se a quilometragem rodada pelo veículo com cada combustível, ou seja, a eficiência energética do etanol é inferior à da gasolina.

Bunde (2011) observa que, nos estados da região Norte do país, normalmente, o preço do litro do etanol está sempre acima dos 70\% comparado com o preço do litro da gasolina. Esse fato faz com que haja baixa demanda de etanol nessa região. 0 preço do etanol superior a $70 \%$ do preço da gasolina nessa região tem dois motivos:

O primeiro deles é que no Brasil a alíquota do Imposto Sobre Circulação de Mercadorias e Serviços (ICMS), que é um imposto estadual cobrado pelo etanol, varia em cada estado. O percentual cobrado gira entre $12 \%$ e $30 \%$. Então, é o valor da alíquota de ICMS cobrado em cada estado que determina o valor do litro do 
etanol e, logo, sua viabilidade econômica, comparado à gasolina. Em alguns estados como São Paulo, Paraná, Bahia, Minas Gerais e Goiás, o valor do ICMS cobrado pelo etanol é menor, o que, por um lado, beneficia os consumidores e aumenta o consumo, mas, por outro, toda a sociedade acaba arcando com os custos deste incentivo. O segundo fator que influencia o preço do etanol é a logística. Os custos dos transportes acabam influenciando o preço nos postos de combustíveis, de cada estado e/ou região do país. Quanto mais longe da usina, mais caro o produto. (BUNDE, 2011, p. 93).

A alíquota do ICMS determinada por cada estado influencia diretamente o consumo de etanol em cada local. "Diante disso, fica evidente que, do ponto de vista econômico, o preço do etanol, comparado proporcionalmente ao da gasolina, é o que determina o seu consumo" (BUNDE, 2011, p. 93-94). A isso, são somados aspectos relacionados a questões de logística.

A partir daí, foi criado o mercado de etanol hidratado no Brasil, concentrado na região Centro-Sul, com destaque para o estado de São Paulo. A título de ilustração, pode-se observar, na Figura 11, a redução do tributo (ICMS) sobre o etanol hidratado comparado com os tributos sobre a gasolina (CIDE, PIS/COFINS e ICMS) por estado, em dezembro de 2016 (em \%).

Em alguns estados, especialmente nos produtores de cana-de-açúcar e de etanol do Centro-Sul, como é o caso do estado de São Paulo, normalmente nos períodos de safra, o preço do litro de etanol corresponde a menos de $70 \%$ do preço do litro da gasolina. Já nos períodos de entressafra, o preço do etanol ultrapassa esse preço. Esta tem sido a tendência nos últimos anos. Mas, como o setor está sendo cada vez mais monopolizado por empresas multinacionais, isso pode ser modificado, em especial, quando ocorrer uma elevação na demanda e nos preços do açúcar no mercado externo, fazendo com que as empresas do setor desviem a cana da produção de etanol para a fabricação de açúcar, o que pode fazer com que o preço do litro do etanol supere os $70 \%$ do preço do litro da gasolina. 
Figura 10 - Redução do tributo (ICMS) sobre o etanol hidratado comparado com os tributos sobre a gasolina (CIDE, PIS/COFINS e ICMS) por estado dezembro de 2016 (em \%)

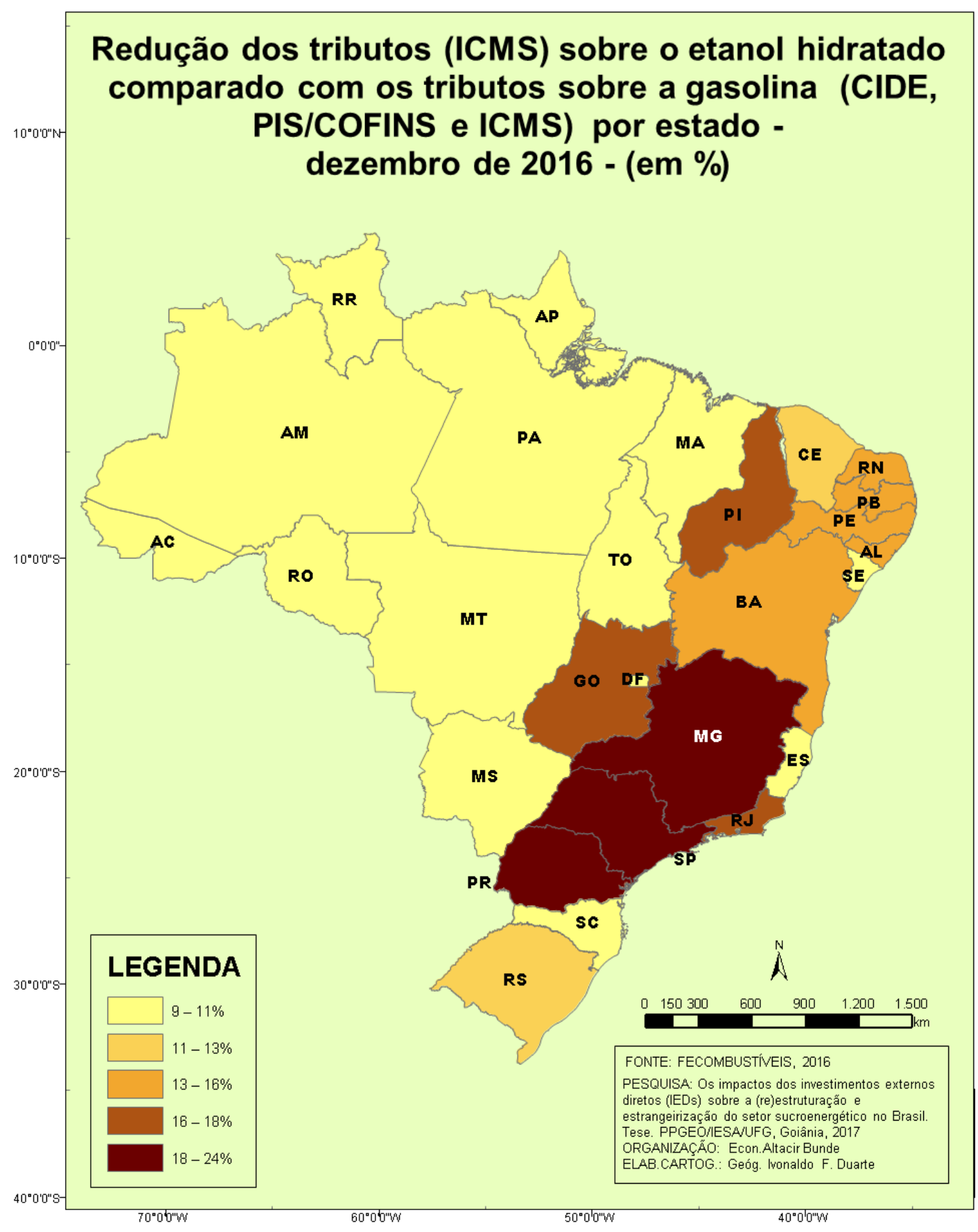

Fonte: Bunde e Duarte (2017), elaborado a partir de dados da FECOMBUSTíVEL 
Se, em alguns períodos do ano, as empresas conseguem manter o preço do litro do etanol inferior a $70 \%$ do preço do litro da gasolina, que estratégias de mercado elas têm utilizado? A primeira delas é pressionar os governos estaduais para que reduzam a alíquota de ICMS cobrado sobre o etanol. A segunda é pressionar o governo federal para elevar o valor da Contribuição de Intervenção no Domínio Econômico (CIDE) e aumentar o percentual de adição de álcool anidro na gasolina. É claro que outras estratégias também são usadas.

Os impostos sobre a formação do preço da gasolina são, basicamente, quatro: um estadual e três federais:

1. Imposto sobre Circulação de Mercadorias e Prestação de Serviços - Tributo estadual. Cada estado determina seu valor. A taxa varia entre estado.

2. Contribuição de Intervenção no Domínio Econômico (CIDE) - Tributo Federal. O valor cobrado é de $2 \%$ sobre o preço do litro de gasolina. O etanol é isento desse imposto.

3. Programa de Integração Social/Programa de Formação do Patrimônio do Servidor Público (PIS) - Tributos Federais.

4. Contribuição para o Financiamento da Seguridade Social - Tributo Federal (COFINS). Somados os dois (PIS + COFINS), a taxa, em 2016, variava entre 7\% e 8\%, dependendo do estado. No etanol hidratado, a taxa é zero.

Pode haver, ainda, tributos municipais que podem incidir sobre o preço dos combustíveis. Contudo, esses são os principais tributos estaduais e federais cuja incidência influi na formação dos respectivos preços de venda de combustíveis, em especial o etanol. No que diz respeito às políticas do governo federal e estaduais, (COSTA; GUILHOTO, 2011, p. 370) argumentam que:

Desde o processo de desregulamentação do setor sucroenergético, finalizado no início da década de 2000, a principal política de intervenção do governo federal no mercado de etanol foi à incorporação de um imposto sobre o consumo da gasolina, a CIDE (Contribuição de Intervenção no Domínio Econômico). A gasolina é o principal substituto ao etanol no 
mercado de combustíveis. Além deste imposto, alguns estados do país apresentam também uma alíquota do Imposto sobre Circulação de Mercadoria e prestação de Serviço (ICMS) diferenciada entre etanol e gasolina, sendo superior para a gasolina em relação ao etanol hidratado. Com a CIDE e a alíquota do ICMS diferenciada sobre o preço da gasolina, o preço final ao consumidor pago pelo etanol hidratado torna-se relativamente mais atraente do que o preço da gasolina na bomba, levando ao aumento do consumo do primeiro. Tais incentivos fiscais tiveram como consequência o aumento da concorrência do etanol hidratado em relação à gasolina, principalmente nos estados que adotam um diferencial tributário maior do ICMS em relação aos demais estados. Nos anos recentes, em virtude do aumento da frota de veículos "flexfuel" no Brasil, esta concorrência tem aumentado pelo fato do consumidor poder escolher entre etanol e gasolina na bomba.

No caso das políticas adotadas pelos estados para favorecer o setor, em reportagem, a Folha de São Paulo, em 03/03/2016ii, mostrou que, no Brasil, 12 estados mudaram, no início do ano de 2016, o valor do ICMS e, em sete deles, a redução beneficiou os usineiros, pois tornou mais competitivo o etanol comparado à gasolina.

A queda, aliada à alta da gasolina, eleva a competitividade do álcool - se o preço for inferior a $70 \%$ do valor da gasolina, ele é mais vantajoso [...] Essa onda pró-etanol, que conta com lobby do setor, iniciou em 2015, quando Minas Gerais criou a maior diferença tributária entre os combustíveis no país ao reduzir a cobrança do etanol de 19\% para $14 \%$ e subir a da gasolina de $27 \%$ para $29 \%$. As vendas de álcool mais que dobraram desde então ${ }^{\mathrm{iii}}$.

Como se pode perceber, os estados produtores de etanol hidratado praticam políticas de ICMS ${ }^{\text {iv }}$ diferenciadas para o produto. Como exemplo, o estado de Minas Gerais reduziu, em 2015, de 19\% para 14\% a alíquota sobre o etanol hidratado e, ao mesmo tempo, aumentou de $27 \%$ para $30 \%$ sobre a gasolina.

De acordo com dados da Federação Nacional do Comércio de Combustíveis e de Lubrificantes - FECOMBUSTÍVEIS, os principais estados produtores de etanol hidratado e suas alíquotas de ICMS praticadas, as maiores diferenças (somando-se os 
tributos federais mais o ICMS sobre a gasolina), da incidência do ICMS do etanol contra a gasolina se dá em: Minas Gerais, 24\%; São Paulo, 23\%; Paraná, 21\%; Goiás, 17\%; Piauí, 18\%; Rio de Janeiro, 17\%. Alagoas e Pernambuco, os dois estados maiores produtores do Nordeste, também passaram a adotar, a partir de 2016, alíquotas de incentivo ao etanol hidratado, sendo que, no primeiro, a diferença é de $16 \%$ e, no segundo, de 15\%, conforme Figura 11.

Figura 11- Redução do tributo (ICMS) sobre o etanol hidratado comparado com os tributos sobre a gasolina (CIDE, PIS/COFINS e ICMS) por estado - dezembro de 2016 (em \%)

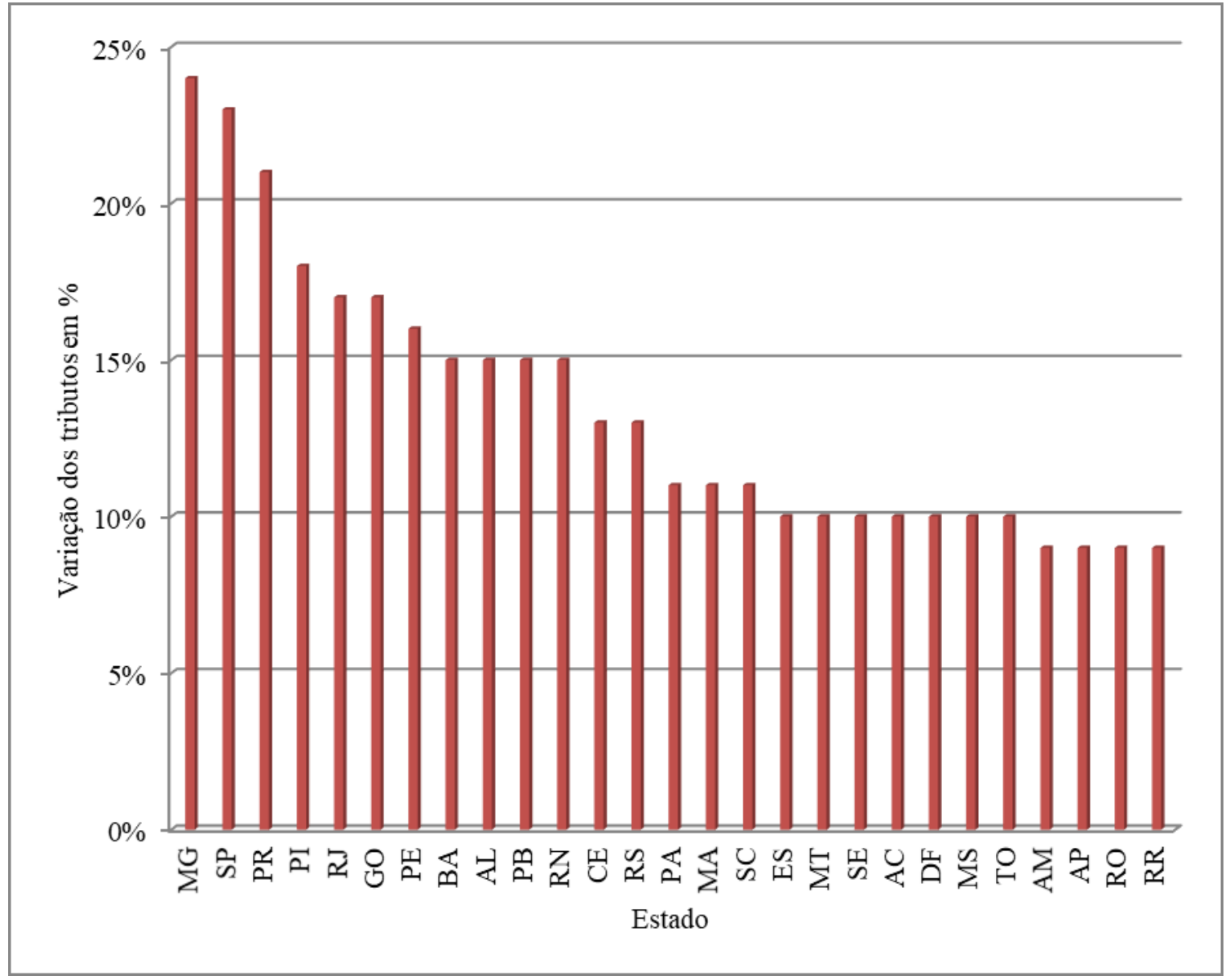

Fonte: Bunde (2017), elaborado a partir de dados da FECOMBUSTíVEIS, 2016

Cabe destacar que a prática não trata apenas de redução do ICMS sobre o etanol hidratado, mas, alguns estados, em 2015 e 2016, além de reduzirem a alíquota sobre 
o produto, elevaram a taxa sobre a gasolina, tornando o produto mais competitivo se comparado com a gasolina, especialmente nos estados do Nordeste.

Ao menos 12 Estados mudaram, no início deste ano (2016), a tributação de combustíveis. Em sete deles, a medida favoreceu usineiros e deu mais competitividade à produção de etanol no país. Cinco Estados elevaram a alíquota de ICMS da gasolina e reduziram a do etanol hidratado. Outros dois subiram só a tributação da gasolina. Em quatro Estados, o índice foi elevado para os dois combustíveis e, em um (Bahia), só houve alta da cobrança incidente no etanol [...] A medida atinge principalmente o Nordeste, onde o consumo de etanol historicamente é baixo. Dos nove Estados da região, cinco reduziram o índice do etanol e subiram o da gasolinav.

Na Tabela 01, pode-se visualizar o valor das alíquotas de tributos federais (CIDE, PIS/COFINS) ${ }^{v i}$, do ICMS sobre a gasolina e o etanol hidratado, e a variação dos tributos (federal + estadual) da gasolina sobre o do etanol hidratado em dezembro de 2016.

Cabe salientar, ainda, conforme dados da Tabela 01, que, na comercialização do etanol, as empresas não pagam tributos federais, ou seja, mesmo com uma série de incentivos concedidos aos grupos econômicos do setor, estes, por sua vez, ainda não pagam impostos ao governo federal. O setor é isento do pagamento de tributo em função de concessões (pacote de bondades) feitas pela ex-presidente Dilma Rousseff (PT), em abril de 2013, para o setor sucroenergético. Se não bastasse a isenção de tributos federais, o governo, na época, concedeu, para o setor, o aumento de 25\% para 27\% de mistura de álcool anidro à gasolina, medida que entrou em vigor em 16 de março de 2015.

Diante disso, é necessário entender essas políticas para explicar a concentração do consumo de etanol hidratado em relação ao consumo nos demais estados, não produtores. Como visto, há uma grande disparidade no consumo de etanol hidratado entre regiões e estados. Essa disparidade existe em função da adoção de políticas de incentivos, e o ICMS é a principal política adota por governos estaduais. 
Tabela 01 - Valor das alíquotas de tributos federal (CIDE, PIS/COFINS), do ICMS sobre a gasolina e o etanol hidratado, e variação dos tributos (Federal + Estadual) da gasolina sobre o do etanol hidratado (em percentual), por estado dezembro de 2016

\begin{tabular}{|c|c|c|c|c|c|c|c|}
\hline UF & $\begin{array}{c}\text { Tributo } \\
\text { Federal } \\
\text { (CIDE) }\end{array}$ & \begin{tabular}{|c|} 
Tributo \\
Federal \\
(Pis/Cofins) \\
\end{tabular} & $\begin{array}{c}\text { Tributos } \\
\text { Federais } \\
\text { (Total) }\end{array}$ & \begin{tabular}{|c|} 
ICMS \\
sobre a \\
gasolina \\
\end{tabular} & $\begin{array}{c}\text { Tributos } \\
\text { (Federal + }^{\text {Estadual) }}{ }^{(1)}\end{array}$ & $\begin{array}{l}\text { ICMS sobre } \\
\text { o etanol (2) }\end{array}$ & $\underset{(1-2)}{\text { Variação }}$ \\
\hline$A C$ & $2 \%$ & $7 \%$ & $9 \%$ & $24 \%$ & $33 \%$ & $23 \%$ & $10 \%$ \\
\hline $\mathrm{AL}$ & $2 \%$ & $8 \%$ & $10 \%$ & $30 \%$ & $40 \%$ & $25 \%$ & $15 \%$ \\
\hline AM & $2 \%$ & $7 \%$ & $9 \%$ & $24 \%$ & $33 \%$ & $24 \%$ & $9 \%$ \\
\hline AP & $2 \%$ & $7 \%$ & $9 \%$ & $25 \%$ & $34 \%$ & $25 \%$ & $9 \%$ \\
\hline $\mathrm{BA}$ & $2 \%$ & $7 \%$ & $9 \%$ & $27 \%$ & $36 \%$ & $21 \%$ & $15 \%$ \\
\hline CE & $2 \%$ & $7 \%$ & $9 \%$ & $28 \%$ & $37 \%$ & $24 \%$ & $13 \%$ \\
\hline DF & $2 \%$ & $8 \%$ & $10 \%$ & $28 \%$ & $38 \%$ & $28 \%$ & $10 \%$ \\
\hline ES & $2 \%$ & $7 \%$ & $9 \%$ & $26 \%$ & $35 \%$ & $25 \%$ & $10 \%$ \\
\hline $\mathrm{GO}$ & $2 \%$ & $7 \%$ & $9 \%$ & $30 \%$ & $39 \%$ & $22 \%$ & $17 \%$ \\
\hline $\mathrm{MA}$ & $2 \%$ & $8 \%$ & $10 \%$ & $27 \%$ & $37 \%$ & $26 \%$ & $11 \%$ \\
\hline MG & $2 \%$ & $7 \%$ & $9 \%$ & $30 \%$ & $39 \%$ & $15 \%$ & $24 \%$ \\
\hline MS & $2 \%$ & $8 \%$ & $10 \%$ & $25 \%$ & $35 \%$ & $25 \%$ & $10 \%$ \\
\hline $\mathrm{MT}$ & $2 \%$ & $7 \%$ & $9 \%$ & $26 \%$ & $35 \%$ & $25 \%$ & $10 \%$ \\
\hline PA & $2 \%$ & $7 \%$ & $9 \%$ & $27 \%$ & $36 \%$ & $25 \%$ & $11 \%$ \\
\hline PB & $2 \%$ & $8 \%$ & $10 \%$ & $30 \%$ & $40 \%$ & $25 \%$ & $15 \%$ \\
\hline$P E$ & $2 \%$ & $8 \%$ & $10 \%$ & $29 \%$ & $39 \%$ & $23 \%$ & $16 \%$ \\
\hline $\mathrm{PI}$ & $2 \%$ & $8 \%$ & $10 \%$ & $27 \%$ & $37 \%$ & $19 \%$ & $18 \%$ \\
\hline PR & $2 \%$ & $8 \%$ & $10 \%$ & $29 \%$ & $39 \%$ & $18 \%$ & $21 \%$ \\
\hline $\mathrm{RJ}$ & $2 \%$ & $7 \%$ & $9 \%$ & $32 \%$ & $41 \%$ & $24 \%$ & $17 \%$ \\
\hline $\mathrm{RN}$ & $2 \%$ & $7 \%$ & $9 \%$ & $29 \%$ & $38 \%$ & $23 \%$ & $15 \%$ \\
\hline RO & $2 \%$ & $7 \%$ & $9 \%$ & $26 \%$ & $35 \%$ & $26 \%$ & $9 \%$ \\
\hline RR & $2 \%$ & $7 \%$ & $9 \%$ & $25 \%$ & $34 \%$ & $25 \%$ & $9 \%$ \\
\hline $\mathrm{RS}$ & $2 \%$ & $7 \%$ & $9 \%$ & $30 \%$ & $39 \%$ & $26 \%$ & $13 \%$ \\
\hline $\mathrm{SC}$ & $2 \%$ & $8 \%$ & $10 \%$ & $25 \%$ & $35 \%$ & $24 \%$ & $11 \%$ \\
\hline SE & $2 \%$ & $7 \%$ & $9 \%$ & $28 \%$ & $37 \%$ & $27 \%$ & $10 \%$ \\
\hline SP & $2 \%$ & $8 \%$ & $10 \%$ & $25 \%$ & $35 \%$ & $12 \%$ & $23 \%$ \\
\hline TO & $2 \%$ & $7 \%$ & $9 \%$ & $29 \%$ & $38 \%$ & $28 \%$ & $10 \%$ \\
\hline
\end{tabular}

Fonte: Bunde (2017), elaborado a partir de informações da FECOMBUSTíVEIS, 2016.

Conforme já apontado por Bunde (2011), a redução da alíquota de ICMS somada aos baixos custos com transporte, devido à proximidade da produção com o centro consumidor, tornam o preço do etanol hidratado abaixo dos $70 \%$ do preço do litro da gasolina tipo C em algumas regiões. No entanto, com a adoção dessas políticas, quem paga a conta é a população, pois tais recursos, que poderiam ser arrecadados e 
canalizados para políticas e serviços públicos, são transferidos para os capitalistas nacionais e estrangeiros do setor.

Diante de todos os elementos discutidos, percebe-se que a formação de um grande mercado de consumo de etanol leva a concentração da produção de etanol próxima a esse mercado e, consequentemente, essa produção é consumida nesse mercado construído pela grande presença de veículos flex. Todavia, isso só é possível devido às políticas de incentivos ao consumo desse produto, em especial, à redução do ICMS, fazendo com que, no setor, permaneça uma política paternalista e protecionista. Portanto, o setor sucroenergético brasileiro se beneficiou e continua a se beneficiar da "generosidade" do Estado, motivo pelo qual cabe dar-lhe a alcunha de Estado mãe.

\section{CONSIDERAÇÕES FINAIS}

A expansão da produção e do consumo de etanol hidratado e anidro no Brasil é um dos principais elementos para explicar a (re)estruturação do setor sucroenergético brasileiro (embora existam outros fatores, internos e externos), especialmente, após os primeiros anos do século XXI. No entanto, não se deve atribuir apenas a esse fenômeno tal acontecimento. A concentração de veículos flex é fundamental, pois cria um enorme mercado para o etanol e é também, um dos principais responsáveis pela expansão da produção.

Diante dos dados apresentados, não basta que alguns estados considerados os maiores produtores de etanol hidratado tenham a maior presença do número de veículos flex para se explicar o elevado consumo de etanol hidratado, especialmente nos estados do Centro-Sul. Certamente isso influencia, mas, sem dúvida, se esses estados não tivessem tornado o produto competitivo, capaz de concorrer com a gasolina tipo C, feito por meio das políticas de redução da taxa de ICMS, a produção e o consumo não teriam crescido da forma como ocorreu nessas frações territoriais. 
Portanto, ao analisar os dados sobre a presença de veículos, a produção e o consumo de etanol, identificou-se que, no estado de São Paulo, estão concentrados $36,8 \%$ da frota total de veículos no Brasil. Além disso, $54,6 \%$ da produção total de etanol anidro e 59,3\% de etanol hidratado, e é onde se consome 58,3\% do total de etanol produzido no país. Mas, esta territorialização numa fração do território brasileiro não é algo natural, mas construído por meio de políticas de proteção ao setor, especialmente pelos governos estaduais. Portanto, no Brasil a (re)estruturação do setor sucroenergético está relacionada as políticas de Estado.

\section{REFERÊNCIAS}

AGÊNCIA NACIONAL DO PETRÓLEO, GÁS NATURAL E BIOCOMBUSTÍVEIS (Brasil). Anuário estatístico brasileiro do petróleo, gás natural e biocombustíveis, 2015. Disponível em: <www.anp.gov.br>. Acesso em: 11 de outubro de 2016

ANDRADE, M. C. A questão do território no Brasil. São Paulo: Hucitec; Recife: IPESPE, 1995.

ASSOCIAÇÃO NACIONAL DOS FABRICANTES DE VEÍCULOS AUTOMOTORES - ANFAVEA. Anuário da indústria automobilística brasileira - 2016. Disponível em: <www.anfavea.com.br>. Acesso em: 23 janeiro de 2017

BACCARIN, J. G. A constituição da nova regulamentação sucroalcooleira. Brasília: UNB; São Paulo: UNESP, 2005.

BUNDE, A. Os impactos do agronegócio dos agrocombustíveis sobre 0 campesinato em Goiás. 2011. 209 p. Dissertação (Mestrado)-Universidade Federal de Goiás, Campus Catalão, Departamento de Geografia.

BUNDE, A. Os impactos dos investimentos externos diretos (IEDs) sobre a (re)estruturação e estrangeirização do setor sucroenergético. 2017. 319 p. Tese (Doutorado em Geografia) -Universidade Federal de Goiás, Instituto de Estudos Socioambientais (lesa), Programa de Pós-Graduação em Geografia, Goiânia (GO).

CALABI, D.; INDOVINA, F. Sobre o uso capitalista do território. Archivio di studi urbani e regionali. Veneza, ano IV, n. 2, junho 1973. (Mimeografado).

CARTILHA DA ASSEMBLEIA POPULAR. Para debater a crise. São Paulo, 2009. 
CONAB - Companhia Nacional de Abastecimento. Acompanhamento safra brasileira. Cana, v. 2 - Safra 2015/16, n. 3 - terceiro levantamento, Brasília, p. 1-65, dezembro 2015. http://www.conab.gov.br/OlalaCMS/uploads/arquivos/15_12_17_09_03_29_boletim_ca na_portugues_-_3o_lev_-_15-16.pdf. Acesso: 23 maio 2015.

COSTA, C. C. da; GUILHOTO, J. J. M. O papel da tributação diferenciada dos combustíveis no desenvolvimento econômico do estado de São Paulo. Economia Aplicada, v. 15, n. 3, 2011, p. 369-390. Disponível em: < http://www.scielo.br/pdf/ecoa/v15n3/a02v15n3.pdf >. Acesso em: 22 de abr. 2016.

COSTA, P.R.M.F. Um estudo de oportunidade para o setor sucroalcooleiro na matriz

energética. Dissertação de Mestrado em Engenharia Elétrica. UNB: Brasília, fevereiro, 2008.

LIMA, J.C.S. A intervenção governamental no setor açucareiro: ênfase à problemática do subsídio de equalização. 1992. Tese (Doutorado)-FEA, USP, São Paulo, 1992.

MARX, K. 1818-1883. O Kapital: Contribuição à crítica da economia política. Tradução e introdução de Florestan Fernandes. 2. ed. São Paulo: Expressão Popular, 2008.

OLIVEIRA, A. U de. A geografia agrária e as transformações territoriais recentes no campo brasileiro. In: CARLOS, A. F. A. (Org.). Novos caminhos da Geografia. São Paulo: Contexto, 1999. p. 63-110.

ORGANIZAÇÃO Mundial da Indústria Automobilística - OICA. Disponível em: <http://www.oica.net/>. Acesso em: 15 de julho de 2016

RAFFESTIN, C. Por uma geografia do poder. Ática, São Paulo, 1993.

SCHWARCZ, L. M.; STARLING, H. M. Brasil: uma biografia. São Paulo: Companhia das letras, 2015.

SHIKIDA, P. F. A. A evolução diferenciada da agroindústria canavieira no Brasil de 1975 a 1995. Cascavel: Edunioeste, 1998. Disponível em: http://bibliotecadigital.fgv.br/ojs/index.php/rbe/article/viewFile/746/1740. Acesso em: 27 de abr. 2016

SHIKIDA, P. F. A; MORAES, M. A. F. D. de; ALVES, L. R. A. Agroindústria canavieira do Brasil: intervencionismo, desregulamentação e neocorporatismo. Revista de Economia e Agronegócio, v. 2, n. 3, p. 361-382. Disponível em: https://www.researchgate.net/profile/Lucilio_Alves/publication/46535159_AgroindAstr ia_canavieira_no_Brasil_intervencionismo_desregulaAAo_e_neocorporativismo/links/5 
5aab19108aea99467241443/AgroindAstria-canavieira-no-Brasil-intervencionismodesregulaAAo-e-neocorporativismo.pdf. Acesso em: 15 abr. 2016.

SIMAS, M. M. O novo papel das national oil companies - NOCs nos mercados internacionais de energia: um estudo de caso dos BRICS. Disponível em: http://www.ie.ufrj.br/images/pesquisa/pesquisa/textos_sem_peq/apresentacao.pdf. Acesso em: 10 nov. 2015.

SINDIPEÇAS E ABIPEÇAS. Relatório da Frota Circulante de 2015. Disponível em: http://www.sindipecas.org.br/sindinews/Economia/R_Frota_Circulante_Marco_2015.p df. Acesso em: 12 dez. 2015.

UNICA - União das Indústrias Canavieiras do Estado de São Paulo. http://www.unica.com.br/. Acesso em: 14 de maio de 2016.

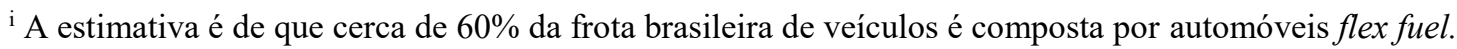

ii Disponível em: <http://www1.folha.uol.com.br/mercado/2016/03/1745717-estados-mudam-aliquota-do-icms-eincentivam-producao-de-etanol.shtml>. Acesso em: 10 maio 2016.

iii Id.

iv $\mathrm{O}$ recolhimento do ICMS do etanol hidratado é diferente dos demais combustíveis, pois é cobrado nas refinarias. No caso do etanol, o produtor (usina) paga o tributo ao vender o combustível a um terceiro.

${ }^{v}$ Disponível em: <http://www1.folha.uol.com.br/mercado/2016/03/1745717-estados-mudam-aliquota-do-icms-eincentivam-producao-de-etanol.shtml >. Acesso em: 10 maio 2016.

vi Os tributos federais estão em consonância com a Lei12.859/2013 e o Decreto 8.395/2015.
} 